\title{
RECRUITMENT TO ARMED GROUPS FROM DISPLACED COMMUNITIES IN NINEWA GOVERNORATE
}

\author{
MaAmoon Abdulsamad Mohammed ${ }^{*}$, SAdiQ SedeEQ Hamid ${ }^{* *}$ and Audrey Watne ${ }^{* * *}$ \\ * Dept. of Peace and Human Rights, University of Duhok, Kurdistan Region-Iraq \\ D** Dept. of Peace and Human Rights, University of Duhok, Kurdistan Region-Iraq \\ Institutional Learning Specialist, New York University-United States
}

(Received: April 11, 2018; Accepted for Publication: August 1, 2018)

\begin{abstract}
(CPCRS) and International Organization of Migration (IOM) collaborated on research on violent youth mobilization and the recruitment efforts of armed groups in Ninewa Governorate. The primary goals of this research were the following: to understand how conflict has affected communities, including the current tensions; to understand and help mitigate "push and pull factors" of mobilization into armed groups; and to discern best practices for stabilization and resilience programming by the aid community.

The four locations are a mix of urban and rural environments in Ninewa Governorate that collectively host IDPs from Mosul and displaced Shebak, Yezidi, and Christian communities. The study used qualitative research interviews with host community members, IDPs, community leaders, and armed group members in each location, followed by focus groups with community members and IDPs.

The study found that motivations for armed group recruitment are complex, interconnected, and relate both to economic concerns (a need for livelihood) and grievances related to previous experiences of marginalization and/or discrimination. The opinions expressed in this article are those of the authors and do not necessarily reflect the views of IOM.
\end{abstract}

KEYWORDS: Armed groups, IDPs, Recruitment, Demobilization, Push and pull factors

\section{INTRODUCTION}

$\mathbf{R}^{\mathrm{e}}$ ecruitment to armed groups among displaced and host communities is an increasing phenomenon in Iraq. A contextual definition of these non-state armed groups, as used in this paper, is that they are unofficial groups of people who organize themselves and are capable of using violence - and actually do so - to achieve their goals. They have a certain degree of autonomy regarding military operations, resources, and infrastructure. However, they may be supported secretly or openly both by state actors and by international actors. While attention has been paid to recruitment among refugee communities and the global diaspora (Thomas 2003), national governments and the international community struggle to give sufficient regard to the unique conditions for recruitment among internally displaced communities. Nevertheless, the greater the understanding that exists regarding the reasons people join armed groups and of these groups' activities and all knowledge about them, the more effectively communities and states will be able to manage their own security and to protect vulnerable populations (Van Brabant, 2000).

Militias and armed groups have held diverse roles in formal and informal governance in Iraq, generally forming in response to a perceived need for security in times of conflict. The number of informal militias and armed groups increased significantly after 2003, particularly after the 2014 ISIS takeover of territory - and Iraq now has between 50-74 insurgent units in addition to several Islamic armed groups (Ozerdem, 2010).

Understanding the diverse motivations for recruitment is a necessary first step in any plan for disarmament, demobilization and reintegration (DDR) or security sector reform (SSR) requirements, and it is essential to enabling the international community and governments to create effective policies to support any hope of future reconciliation. The study approaches this 
problem by focusing on the current displacement crisis in disputed territories in Northern Iraq.

\subsection{Context}

In Iraq, there is sometimes confusion as to who are IDPs, returnees, or refugees, and this compounds the difficulties in understanding and in the politicization of those terms. Due to conflicting identities, Arab Iraqi IDPs face greater integration challenges while Syrian Kurdish refugees may integrate more easily in Kurdish controlled areas. Moreover, there have been many displacements in Iraq, so whenever IDPs, returnees, and refugees are mentioned, specificity is required.

Despite some literature which argues that there are similarities in the reasons for the flight of IDPs and refugees (Lischer 2008), there have been significant criticisms of methodologies that treat all displacement and migration as the same. To be fully understood, each displacement should to be examined uniquely based on the reasons for displacement, the country context, and the historical background of the displacement.

In contrast with IDPs, refugees are protected by internationally recognized laws and receive help from the international community as international conventions oblige states to allow asylum for refugees (Thomas, 2003). Thus, to some extent, international non-governmental organizations (INGOs) are free to work with refugees and refugees are entitled to greater protection in their places of refuge. On the other hand, the problems of IDPs are more political and, while the international community may deal with the challenges they face as a humanitarian crisis, these interventions are short term remedies and do not address the root causes of displacement, especially conflict-related displacement. Moreover, because of state sovereignty issues, the international community finds it difficult to intervene as it would like, and states often seek to hide or avoid sharing knowledge about the issues involved. Meanwhile, there are no international conventions that hold states responsible for protecting IDPs. Nonetheless, they have been protected under several bodies of law, including international human rights law and domestic law.

This paper focuses on the last exodus/displacement after the so-called Islamic State (ISIS) occupied Ninewa in 2014. As ISIS targeted anyone non-conformant with their ideas and beliefs, people collectively fled the requirement to conform to ISIS's demands or be killed.

Historically, this area has experienced repeated displacement due to Arabization policies (Stansfield 2003:75) and more recent increases in Kurdish autonomy. For example, in the 1940's, Jewish communities faced threats to leave or face violence and, after the 2003 regime change, Sunni Muslims living in mostly Shiia Muslim areas saw their homes marked with threats forcing them to leave, and vice versa in Sunni areas (UoD, 2017).

Government policy, or lack thereof, has exacerbated the situation in a number of ways. First, Iraqi identity cards state the ethnicity and religion of each individual, making it easy for individuals to be treated according to their in group or out group status. Under the Arabization policy in the 1980's, Saddam Hussein's Iraqi government at times gathered the Kurds together and put them in camps (Bahrke) and at other times they scattered the Kurds to different places in Iraq. The government also confiscated their land and gave properties to Arabs of the south. The Iraqi government used this displacement policy as a means to maintain their power as well as to carry out ethnic cleansing and as a collective punishment for the minority group. This has caused deep seated resentment among Kurdish populations and made their situation more vulnerable, especially for those IDPs that are not of the ethnicity or religion of majority groups in areas where they have fled to, especially the Kurdistan region (Stansfield 2003).

The process of marginalization of others continued after the Iraqi regime change in 2003 with the marginalization on the Sunni Muslim population. The greed and grievances of previously marginalized groups fed on this long history of violence and marginalization of Shiia Muslims and other minorities. The policy of the Iraqi government involved arming the tribal leaders to provide security and, through this, warlords gained money and privilege from the armed groups.

These historic phases of displacement and marginalization contribute to the issue of layered land disputes which are very complicated to resolve despite the existence of legal documents and historical records. In many cases, previous land owners individually and collectively find the only way they can retake their previously owned land is by force, further reinforcing the cycle of 
displacement in Iraq. This cycle continues a process of internal colonialism deeply embedded in the institutions of society, making it very difficult to be resolved. The treatment of minority areas in disputed territories (such as Sinjar) provides good examples of this policy as the majority populations use colonial methods to control minority groups. As scholars such as Edward Azar (1990) and Daniel Bar-Tal (1990) argue, a long history of ethnocentrism and ethnic intolerance tends to lead to conflict and to make the conflict more protracted, as witnessed in Northern Iraq.

Moreover, the specifics of the war with ISIS are clearly a crucial part of the displacement context where the most targeted and affected people were non-Muslims or anyone who did not conform to ISIS ideology and beliefs, such as Shiia Muslims/Turkmen and the Kurds. Other religious groups who are not defined by ISIS as "people of the book" (followers of monotheistic religions) faced worse treatment: forced conversion to Islam or death. Women were used as products to be sold and bought in the market. For Yezidi populations, the ISIS takeover was highly traumatic (though unfortunately not unique as this is the 74th such genocidal catastrophe they have experienced).

These conflicts aimed at domination of one group over all others is a type of war that Kaldor (1999) discusses: new wars with the goal of terrorizing people as a means to win in war, using the displacement of civilians as a key objective leaving people no options except displacement to save their lives. Thus, displaced people are incidental outcomes of conflict aimed at domination.

Additionally, laws and the context of the disputed territories (Article 140) are also complex and inadequate. According to Article 9/1/B of the Iraqi Constitution, the formation of militias outside the framework of the armed forces is prohibited and according to article $121 / 5$, the regional government shall be responsible for all the administrative requirement of the region particularly the establishment and the organisation of the internal security forces for the region, such as police, security, forces and guards of the region (Constitution of Iraq 2005).

In relation to policy regarding armed groups, the government does not have a register of the armed groups and militias, which according to the constitution should be under the supervision of Iraqi government army. Moreover, despite the many conflicts and wars in Iraq, there has never been an official DDR policy. This lack of security and inadequacy of laws, combined with the deBaathification of the Iraqi military in 2004, a culture of masculinity, and collectivism in defending oneself and one's group by force (especially strong in the disputed areas where the power vacuum made the situation worse), creates a context in which IDPs seek their own methods of self-defence via armed groups.

\section{MATERIALS AND METHODS \\ 2.1 Research Aims}

This writing is based on a study on conflict dynamics and non-state armed groups in Northern Iraq which took place between December 2016 and March 2017. The study was a collaboration between IOM and the University of Duhok and focused on four towns in north-east Ninewa. After explaining some of the challenges facing such research, this paper discusses the context in which recruitment takes place and a detailed explanation of the drivers and pull factors involved.

\subsection{Research Areas}

Data for this report was collected from four locations within north-east Ninewa. To protect the identity of respondents, the locations have been anonymized; however, they are characterized as follows: 
Table (1): Table of Research Locations

\begin{tabular}{|c|c|c|c|}
\hline Area 1 & Area 2 & Area 3 & Area 4 \\
\hline Majority Christian town. & $\begin{array}{l}\text { Agricultural town of mixed } \\
\text { ethnicities and religions. }\end{array}$ & $\begin{array}{l}\text { Agricultural town of mixed } \\
\text { ethnicities and religions. }\end{array}$ & Primarily Yezidi town. \\
\hline $\begin{array}{l}\text { IDPs are Christians mostly } \\
\text { displaced by ISIS from Mosul. }\end{array}$ & $\begin{array}{l}\text { IDPs include Yezidi, Arab, } \\
\text { Kakai, Shabak, and Kurds. }\end{array}$ & $\begin{array}{l}\text { IDPs include Yezidi, Arab, } \\
\text { Kakai, Shabak, Turkman and } \\
\text { Kurds. }\end{array}$ & $\begin{array}{l}\text { IDPs are Yezidi displaced by } \\
\text { ISIS. }\end{array}$ \\
\hline $\begin{array}{l}\text { IDPs living in rented homes, } \\
\text { with host families, and in } \\
\text { religious buildings. }\end{array}$ & $\begin{array}{l}\text { IDPs are both in camps and } \\
\text { in rented homes and with } \\
\text { host families. }\end{array}$ & $\begin{array}{l}\text { IDPs are both in camps and } \\
\text { in rented homes and with } \\
\text { host families. }\end{array}$ & $\begin{array}{l}\text { IDPs are living in the town in } \\
\text { rented homes, with host } \\
\text { family, and in informal } \\
\text { settlements. }\end{array}$ \\
\hline
\end{tabular}

\subsection{Research Methods}

For each location, the Center for Peace and Conflict Resolution Studies, University of Duhok, provided two researchers who partnered with two data collectors from each town, who were trained in data collection, use of the study instruments, and peace and conflict methods and subjects. The total dataset included 88 interviews and 16 focus group discussions (which included group discussion around questions and the creation of eight conflict maps from each community). In each location, 22 interviews were completed, engaging an approximately equal mix of IDPs, host community members, men and women. Two armed group members were interviewed in each location. In addition, four focus group discussions were conducted in each location: two with IDPs and two with the host community, with a roughly equal balance of men and women.

Interview questions related to recruitment by and mobilization of violent groups to develop a profile of who is most affected; the motivations, incentives, and enabling factors of those affected; how aid is impacting people's decisions to join militias; how aid can be structured to prevent recruitment by armed groups; and how the aid community can accordingly change practices and behaviour. Focus group methodology included conflict mapping to create community profiles which were used to explore the tensions, connectors and dividers, structural motivators for armed mobilization, factors related to demobilization, and the relation between displacement and armed mobilization.

\subsection{Challenges for this Research}

There are certain contextual and systematic challenges which face any researcher who writes about displacement and especially recruitment (Hotzam, 2004; Stoddard, 2004). Due to the topics' political sensitivity and complexity, there has been little written about these, particularly because it may not benefit local politicians or governments to gather information about recruitment. Scholars emphasize the importance of taking this sensitivity into consideration when collecting data as it may affect the people who have joined the groups, the armed groups, and the credibility and the validity of data gathered (Collinson et al., 2002). Hence, researchers of this writing have taken this reality into consideration in the whole process of collecting and analysing the data. Knowledge about IDPs is highly political in disputed areas as it affects the future of those areas, whose status remains disputed following the 2017 referendum for Kurdish independence.

There are also specific problems relating to the methodology of collecting data on IDPs, since their experiences, concerns, and even their population numbers are highly politicized and contested. Sometimes governmental actors and NGOs manipulate data relating to these issues (i.e., they may inflate or deflate their numbers). Moreover, there is a lack of a systematic method of studying the unique context of IDPs and consequently a lack of reliable data. Like refugees, many IDPs are living outside of camps in rented houses which makes them difficult to trace (UNHCR and the IDP Working Group, 2008). In countries experiencing displacement, statistics of 
the population generally are not effectively maintained, casting doubt over government produced demographics for IDPs. Since the conflict of 2014, the government and INGOs also lack longitudinal studies on when and why IDPs moved to specific places during their displacement.

\section{FINDINGS}

\subsection{Recruitment}

Perception of armed groups varied and there were no communities that were purely positive or negative about non-state armed groups. The community's approval or disapproval of an armed group depended on how effective the groups were in providing security and social services. Some respondents said the groups demonstrated their effectiveness in their operations in Mosul and their collaboration with government forces, including rescuing captives held by ISIS. Communities also responded positively regarding armed groups providing services such as cleaning up retaken areas from mines, distributing aid and food, assisting IDPs in escaping from ISIS, protecting property of IDPs who remained displaced.

Some respondents expressed a dilemma between concerns that the presence of armed groups after liberation may lead to easy access to weapons, and concerns that they may in the future need to rely on armed groups to provide security. Other concerns included the non-state groups' ethno-sectarian affiliations which, they say, have the potential to further break the social fabric of communities and their lack of affiliation with or accountability to official government security.

The research found that recruitment was more common in mixed communities than homogenous communities and a variety of recruitment techniques were used. In mixed communities, different methods were used to recruit people from different ethnic communities. These methods included social media outreach, visits to IDP camps, phone contacts, contacts made in locations including markets, mosques, and high school; moreover, in some cases very low requirements for joining were required.

There were differences between the mixed communities and the homogeneous communities in the reasons given for joining armed groups while some reasons were common to both. In the homogenous communities, individuals reported joining armed groups for various reasons: to defend their land and religious identity, in the hope of returning to previously inhabited areas, a desire for justice and revenge including avenging lost family honour, rescuing kidnapped women, and to counter the impunity for those who committed atrocities against the community. Additionally, homogenous communities noted the role of armed groups in providing services and preparing for protracted violent conflicts. In some cases, homogenous groups also reported forced recruitment. Informants mentioned that the lack of a justice system motivates people to join armed group as people have the desire to revenge. Some armed groups informants said that they know who has committed or incited the violence against them. A final reason reported in homogenous communities relates to the discrimination they face and their need to protect their culture and identity. They reported a desire for acceptance and status or social recognition which they sought through participation in an armed group.

In mixed communities, people reported joining armed groups out of interest in the liberation of Mosul and interest in immediate opportunity for employment via enlistment. Armed groups also provided opportunities and activities for group outsiders who faced difficulty in enlisting with normalized groups.

The common factors in the homogenous and mixed communities were poverty and economic need (especially youth unemployment) and operating within a context fraught with lack of governance, corruption, and a security vacuum resultant from state failure. Additional common factors included an interest in liberating one's land and defending one's country and identity.

IDPs expressed feelings of high vulnerability due to their inability to return or to fully integrate into host community society and to the loss of their homes and property. They found themselves starting from nothing without help with recovery. The displaced were highly concerned with economic livelihoods and the primary motivation to join armed groups was to earn a salary. Their return areas lacked basic services, security, and employment provide armed groups with opportunity to take advantage of returnees.

However, the research found that, in the absence of basic services, justice and security in newly liberated areas, non-state armed groups play an important role by providing security and social 
services. Therefore, once they return, IDPs are likely to join non-state armed groups.

The study found challenges facing demobilization of armed groups including a security vacuum and individualized solutions to national security crises, unemployment, and proliferation of weapons, with potential resultant increases in criminal activity. Respondents expressed a lack of political faith, as the majorities of those armed groups belong to politicians and eminent people in the government or community leaders of their communities. They noted that armed group leadership proximity to national government can be used to give legitimacy to illegal armed activities. Armed groups also easily obtain funds from regional powers to serve as proxies for regional power interests.

IDPs were mostly positive about the armed groups and were worried about future demobilization or disbanding as they felt it would lead to the deterioration of security and have a negative impact on the already weak economy. They expressed concerns that the host community and the government will be unable to absorb the large number of ex-combatants. In contrast, the host community were more supportive of demobilization as they see the increase in armed groups destabilizing the security of the area.

However, the research found some opportunities for demobilizing the armed groups: the armed group leadership proximity to national legal systems of governance may provide pathways to normalization; the opportunity for international community engagement to provide protection of minority groups; and the significant interest of recruited members to participate in legal military forces or opportunities to participate in the formal economy, which will help the community trust in the government forces.

This study found similarities in reasons for withdrawing from armed groups in the homogenous, mixed communities. Informants argued that areas were liberated (armed groups not needed now), changing views of religion and politics (realization of misunderstanding and misinterpretation of religion), pressure on groups to normalize may lead to disbanding, personal relationships (pressure from friends, relatives, mentors), armed groups creating fear, instability, and proliferation of weapons (increases stigma of involvement), awareness that armed groups use IDPs as expendable soldiers and send minority members to front lines.

Overall, the findings indicate that government and INGOs lack interest in funding adequate research on the subject.

\subsection{Tension and Conflict}

The study also found that tensions in the communities were a significant factor in recruitment to armed groups. These were various, as discussed below, and exacerbated by the absence of rule of law and reliance on informal conflict resolution mechanisms.

3.2.1 Unresolved historical tensions and contested issues: The disputed territories have historical tensions and problems regarding land, autonomy, participation, recognition, and distribution of other resources due to the bad policies of previous Iraqi government.

3.2.2 Power control and political tension: Respondents argued that political leadership plays an important role in fomenting tension. In each location there is tension among political parties over who controls areas and unequal access to political power.

3.2.3 Identity conflict and sectarianism: Both host community and IDP informants reported religious and ethnic conflict between and within ethnic groups; as well as rural vs. urban income gaps, cultural expectations and stereotypes. Informants reported that political leaders manipulate sectarian and religious discourses for their own benefit.

3.2.4 Social and cultural conflict: Informants stated that there is daily tension between the host community and IDPs. These included differences in daily practices, language difference, and differing ethnic clothing styles. Reliance on informal conflict resolution mechanisms tends to entrench differences.

3.2.5 Economic conflict: With the economic crisis in the region, the rate of unemployment and poverty is high, exacerbating competition over employment between the host community and IDPs. The host community believed that IDPs have distorted the job market and depressed wages.

3.2.6 Resources allocation: The respondents complained about the inadequate and inequitable access to the land and infrastructure, as well as insufficient schools to reach all IDP communities. 3.2.7 Effects of international humanitarian aid: The study further looked at the role of INGOs on 
improving or deteriorating relations between IDPs and the host community. Humanitarian aid was providing for some basic needs, but respondents reported that opaque distribution systems and insufficient amounts of aid (as well as a lack of aid for host community populations) caused tensions. The tensions also often developed over NGO job distribution. Notably, respondents may have limited their feedback about humanitarian aid because they may have felt uncomfortable criticizing aid to data collectors who they perceived to be representatives of IOM and who may have some degree of control over future distribution.

\section{DISCUSSION}

To elucidate the situation, this discussion first examines the relations of authority and influence to recruitment, second, it explains the formative issues indicated by the results and, lastly, it considers possible future triggers for increased armed group recruitment and activity.

\subsection{Authority, influence and recruitment}

Weber (1958) categorizes sources of authority and influence according to levels whereby people are understood to rely on tradition, rational thought, or charismatic influence to legitimize their actions. As will be discussed below, the forms of influence interlink, making them all the more effective.

First, the informants' responses highlighted the fundamental historical issues, sectarianism and tensions between and within groups; these not only constitute significant driving factors in mobilizing recruitment but also present clear opportunities to respond to these pressures since each ethnic group has its own armed group. Traditional influence is fundamental to this: people conform and comply with cultural norms. Hence, elites find a ready environment to manipulate the discourses of inequality to their own interests. In the context of such a collective society, serving the elites means serving all the community. Stewart and Fitzgerald (2001) argued that class differences were used by elites to manipulate people and increase group consciousness of their sufferings. Stewart (2002) in his case study work demonstrates that horizontal inequalities frequently have their origin in historical circumstances - often resulting from colonial policy which privileged some groups over others. This has been the case throughout the history of Iraq, the politics of the ruling classes in Iraq being either to have it all or to lose it all.

Community members expressed that they do not see themselves as citizens of the state, but as citizens of the community. The depth at which inequality, unemployment, repression, ethnic intolerance, discrimination, stereotypes, hostilities, corruption, segregation, educational bias, preference of one groups over another, historical religious hatred, ethnic competition for land and resources, and absence of the rule of law are embedded in society will require long term solutions. Awareness of the depths of these problems has led people to despair and helplessness, and the lack of alternatives makes them rely on informal conflict resolution mechanisms rooted in historic identities, including informal armed groups.

Second, in addition to historical polices, informants noted the effect of current discriminatory policies and current tensions between host communities and displaced communities in a highly insecure context. Many informants indicated that the lack of governance, corruption, nepotism, interest in liberating one's land and defending one's identity, security vacuum, state failure, fear of repetition of atrocities, lack of trust of others, infrastructure mismanagement, destruction of religious places and regional power manipulation of armed groups as proxies to interests in Iraq are among the factors that lead people to join the armed groups. IDP informants noted that the lack of confidence in the Iraqi government to provide security led people to join the armed groups so as to be able to return home more quickly. Moreover, the armed groups are providing services to the people (services notably absent for minority communities), such as cleaning campaigns, which improve the armed group's reputation and attracts more people. Kaufmann (1996) suggests that members of ethnic groups are likely to join armed groups out of concern for their safety. In the newly liberated areas, each particular group secures its own members, so if civilians do not join one particular group, they are not protected.

The third factor is the basic living situation of the IDP communities: primarily characterized by unemployment and deprivation. The marginalisation and displacement of specific ethnic groups means that the needs of IDPs are not 
met on many levels. According to human needs theory, as demonstrated by Maslow (1954), John Burton (1990), and Max-Neef Manfred (1992), people strive to meet their unmet needs, leading to frustration and conflict. Burton further argues that the culture and education of a group manipulates issues and tends to dehumanize other groups. Burton focused on people's rights to identity, recognition and security, and when these are neglected it leads people to use violence to claim those rights, which are non-negotiable.

This research confirmed that politics and economics are intertwined and make vulnerability more complex. Several IDPs said that they do not plan to return but they want build their life from the start and that employment is their first priority as they want to settle in their place. They see no future in the place of return, as everything they had built for years has gone leading them to feel despair. Minority group members reported limited access to economic resources due to a lack of fair distribution, which also led them to despair and hopelessness as there is no law or protection. Our informants indicated a broad range of interrelated drivers and pull factors relating to recruitment. At the more immediate level, these included economic deprivation, unemployment, fear and resentment concerning recent violence.

Hence, the IDPs are the most affected by the outcomes of the war with ISIS; meanwhile, they are the least taken care of after their area is liberated. There is also the lack of systematic study of their needs and concerns throughout Iraq. What makes this displacement different from the other displacement elsewhere in the world? In this case, the situation is especially fragile as the status of disputed areas is still pending and this makes the area more vulnerable to the misuse and manipulation of IDPs.

The final factor is the effect of acute discrimination including displacement and traumatic violence. For instance, it is well known that ISIS raped women resulting in pregnancies and children. The problems arising from this are complex. When some of these children returned from captivity, they experienced stigmatization as the Yezidi community struggled to trust returnees, even children. Historically, Yezidis in Iraq have found it difficult to obtain government identification as they are required to provide religious identification and some Yezidi communities did not want to identify their religion on identity cards. This lack of identification and official papers has made their situation harder to resolve, increased challenges of return, and fuelled a perceived need for self-defence.

\subsection{Formative Issues}

4.2.1 Economic Inequalities: As discussed above, economic inequality is layered and deeply related to motivations for recruitment. Sources of economic inequality include access to employment and humanitarian aid, land access and loss of land due to confiscation or forced migration, and discrimination in markets. IDP informants experienced discrimination when applying for government jobs outside of their own region and unequal access to positions in international and national humanitarian NGOs. They also reported NGOs giving them primarily volunteer opportunities rather than paid positions and expressed frustration that NGOs posted positions primarily on internet platforms which IDPs struggle to access. Additionally, the lack of communication, coordination, and general involvement between host community and displaced community members in designing and implementing projects leads to tensions regarding opportunity and resource distribution between IDPs and host communities.

In many cases, IDPs' land has been sold and bought by many owners or has been seized by a person connected to the government. Moreover, insufficient laws and historical impunity for land grabs have made it very difficult for IDPs to establish land ownership and return to land previously confiscated.

IDPs also reported facing discrimination in local markets. For example Yezidis cannot sell their yogurt in the Muslims' shops because some Muslims consider any food produced by Yezidis not 'halal' and therefore prohibited, making any livelihood based on agriculture while displaced very difficult.

4.2.2 Horizontal Inequalities: Stewart (2002: 1) defines horizontal inequalities as "systematic inequalities between culturally formed groups". In relation to our study, one can link the horizontal inequalities to other classifications of groups, such as gender, ethnic origin, language, locations, rural vs. urban groups. It is also easy for people to be characterized and identified not only through the way they dress (i.e. Arabic dress is different from Kurdish dress), but also through language (Kurdish vs Arabic) and schools and their 
curricula (KRG school's curriculum is different to the Syrian curriculum and the Baghdad curriculum). This raises the question: Is identity the way that people identify themselves or the way that government or dominant groups assign identity to people? Moreover, the implications of identity need to be taken into consideration by humanitarian aid organisations.

Stewart (2002) argued that social inequality can happen through challenges regarding access to education and employment. The IDP informants indicated the tension and frustration they get through the policies and unfair distribution of education resources. They stated that many IDP youths miss school due to lack of schools, or the years spent in schools in Mosul during ISIS' time are not counted by the education district. This caused them frustration and led IDPs to leave the schools. Hence, IDPs become jobless and they have nothing to do, so they join the armed groups - this agrees with Collier's (2000) argument that in societies where education among youths is decreasing, this tends to make the youth more vulnerable to the pressure from home and elites to manipulate them. Moreover, there are grievances based on poverty and political alienation which motivate people to join the armed groups. The government might enable other communities to have fair access to the resources and their participation is fair but, for minorities, their part in this is well below their expectations.

4.2.3 Tribal code of conduct: IDPs and host communities also operate in a context in which tribal affiliation affects identity and status. According to the tribal code of conduct, families operate as unified groups with cultural and traditional norms. Within tribal structures, community and family leaders hold influential roles and use the dynamic power that they have over people to persuade them to join armed groups or demobilize them. These leaders are key communicators and persuaders of community groups and they can influence perceptions of armed groups; moreover, the leaders of armed groups are often eminent people with tribal authority and power.

\subsection{Triggers}

The displacement in Iraq in 2014 was unique compared to previous displacements, and the subsequent trauma and losses faced by individuals and communities has had an effect on triggers for increased recruitment. Most IDPs lost everything as the protracted conflict continued and they have lost hope of returning to areas with weak services and security. Despite their limited economic capacities, the host communities and the KRG have done their best to protect and host more than 1.5 million IDPs and refugees since 2011. However, they have not been able to ameliorate all issues that act as triggers.

Additional trigger points for tensions involve the misunderstandings and misconceptions between host communities and displaced communities due to a lack of communication and understanding between the different communities. Added to this, there is further tension because some populations of IDPs have come from rural environments and resettled in urban environments without transferable skills.

\section{RECOMMENDATIONS}

Drawing on the information and insights from the study respondents, data collectors and the project research team, this paper makes the following recommendations regarding how recruitment to armed groups from IDP communities can be addressed.

\subsection{From communities:}

Community members recommended prioritizing economic opportunities for young people who may otherwise become engaged with armed groups. They also emphasized the need for governmental and societal encouragement of peaceful coexistence of all groups and more opportunities for the different communities to share their unique cultural or religious identities and engage in dialogue with other ethnic groups. Additionally, communities recommended that there be more concrete ways for community members to reject sectarian and racist rhetoric from all sides, increased institutional protection of minority rights, and that the local and international community should spread a culture of tolerance and acceptance of others with a focus on future generations in order to ensure a better future for the society.

\subsection{From research team:}

The research team notes the need for further research into the reasons why IDPs choose some areas to migrate to rather than other areas. This will help policy makers to understand the organization of IDPs during the conflict and make plans and strategies based on those reasons. 
Additional research is also needed to understand why some people stayed in a place of conflict and do not migrate. This background information about demographic changes and displacement motivations and patterns could provide a foundation for the development of guidelines for new research in the field of recruitment and security within internally displaced populations. Researchers should also seek to examine the multifaceted identity-based and grievance-driven reasons that individuals join armed groups in order to design policy to address recruitment. Without more research and assessment, it will be difficult to understand the boundaries of war economy, the survival and coping economy, and how all these factors are interconnected and influence one another.

\subsection{For INGOs and international community}

The international humanitarian aid community can provide leadership in understanding and addressing recruitment by increasing collaboration and data sharing to improve program design and implementation, collaborate to create toolkits and resources, and place IDPs and host communities in the centre of the design and implementation of programs. NGOs should seek to increase communication with community members and community leaders to increase mutual understanding of concerns and constraints. NGOs must also be aware of the precarious economic situation of IDPs and the host community in Ninewa and manage expectations carefully, seeking to understand the impact programme changes have on individual lives and the limitations of relying on volunteers to implement programmes. The UN`s role can be crucial in finding political solutions for the area - especially so in the disputed territories, as well as in finding solutions to the ongoing disputes between the KRG and the federal government.

\subsection{For governments (local and national) addressing recruitment}

Governments can address the prevalence of armed groups in Iraq by seeking to reform laws that reinforce discrimination and marginalize minority communities. They also need to take a more active approach to understanding the numbers and activities of non-state armed activity (i.e., by requiring armed groups to affiliate with the state and to collect soldier rosters to understand how many people join armed groups and to help with post-conflict reintegration of soldiers), and to enforce minimum training and equipment provided by armed groups.

\subsection{For local civil society}

Local civil society can engage more actively in community education and information sharing as well as creating alternative activities for youths and work opportunities to stimulate local employment generation. Civil society can liaise between top leadership and grassroots community levels and collaborate with NGOs to inform and improve NGO practices.

\section{CONCLUSION}

The research found that protracted security complexities play an important role in the existence of the non-state armed groups: the security power vacuum and the existence of a multiplicity of different ethnic groups that have historical hatred within and among groups (each with its own armed group) and no one single nonstate armed groups controlling these areas. Moreover, there are tensions and competition between these groups, which are all aiming to legitimize their existence and have more control over people. The existence of non-state armed groups demonstrates the political and cultural demands for these groups. It reflects both the lack of trust between these communities (because they fear such conflict may happen again) and the lack of trust the communities have in the Iraqi government's ability and willingness to ensure that it will not happen again. To date, these communities have not seen real changes that will make sure the context will change for the better.

The de facto presence of these armed groups, which control the security situation, makes demobilization especially problematic. There is a lack of government motivation to replace them as some have cooperated with the government in liberating places. Moreover, some of these groups are linked to regional states. Thus, demobilizing them requires combined international and government efforts. This is likely to present major challenges after the military operation of Mosul ended. Also, at the social level, the research found that if any demobilization of ex-combatants is going to happen, it will require an integrated approach that takes all the communities into account. Therefore, INGOs and government must also take the identity factor seriously in demobilization and reintegration initiatives. More 
importantly, any such initiatives need to be designed and accepted by all communities and target all communities.

Thus, the IDPs' vulnerability, lack of trust in government apparatus, as well as within communities and among communities, combined with the long history of government policy of marginalization, discrimination and continual outbreaks of violence against these, has made people despair. This policy of division and dominance of one group over others has become internalized and systematized in the laws and institutions in Iraq. The current challenging context of the IDPs, including the prevalence of tension within and among communities, the effects of the protracted conflict and the availability of independent armed groups representing groups' political demands, then motivates them to join those groups. Thus, old grievances and current deprivation, marginalisation and trauma, coupled with social pressure to take revenge and the availability of leadership that can mobilize people, all form a complex network of reasons compelling displaced people to become involved in armed groups.

In the absence of an international system for dealing with IDPs' situations, indeed, before such a system can be set up, it is important to develop a framework of normative standards, institutions and arrangements to guide the actions both of governments and of international humanitarian and development agencies, Moreover, this requires specific understanding of the issues involved, making studies, such as the one described here, an essential starting point for developing a relevant system.

\section{REFERENCES}

- Alfaiad, A. (2005). A Detail Reading of the Draft of Iraqi Constitution. Iraq: Al-kader. Retrieved December 11, 2013, from http://www.alkader.net

- Azar, E. (1990). The management of protracted social conflict: theory and cases. Aldershot: Dartmouth Pub.

- Bar-Tal, D. (1990). Causes and consequences of delegitimization: Models of conflict and ethnocentrism. Journal of Social Issues, 46(1), 65-81.

- Burton, J. (1990). Conflict human needs theory. New York: St. Martin Press.

- Collier, P. (2000). Doing well out of war: An economic perspective. In B. Mats, \& M. M.
David (Eds.), Greed and Grievance: Economic agenda in civil war (pp. 91-111). London: Lynne Rienner.

- Collin, S. (2003). Power, livelihoods and conflict: case studies in political economy analysis for humanitarian action. Overseas Development Institute, London: Human Policy Group Report 13.

- Collinson, S. et al. (2002). Politically Informed Humanitarian Programming: Using a Political Economy Approach, Network Paper 41. London: ODI.

- Kaldor, M. (1999). New and Old wars: Organised violence in global era. Cambridge: Polity Press.

- Kaufman, S. (1996). An international theory of interethnic war. Review of International Studies, 22(2), 149-171.

- Lischer, S. K. (2006). War, Displacement, and the Recruitment of Child Soldiers. Pittsburgh: Ford Institute.

- Lischer, S. K. (2008). Security and displacement in Iraq. International Security, 33(2), 95-119.

- Max-Neef, M. (1992). Human Scale Development: Conception, Application and Further Reflections. New York: The Apex Press.

- Maslow, A. H. (1954). Motivation and personality. New York: Harper.

- Özerdem, A. (2010). Insurgency, militias and DDR as part of security sector reconstruction in Iraq: how not to do it. The Journal of Disaster Studies, Policy and Management, S40-S59.

- Stansfield, G. (2003). Iraqi Kurdistan: Political development and Emergent Democracy. London: Routledge Curzon.

- Stewart, F. (2002). Horizontal Inequalities: A Neglected Dimension of Development. Working Paper No. 81. QEH working paper series.

- Stewart, F. and Fitzgerald, V. (2001). War and Underdevelopment: The Economic and Social Consequences of Conflict. Oxford, Oxford University Press.

- Stoddard S., B. (2004). Every one`s and no one`s: IDPs, refugees, and the politics of aiding the displaced. In N. N. Goldstein (Ed.), The politics of forced migration: A conceptual, operation and legal Analysis (pp. 87-100). America: Baltimore.

- Thomas, G. W. (2003). Internal Exiles: What next for internally displaced persons. Journal of Third World Quarterly, 49, 429-447.

- United Nations High Commissioner for Refugees (UNHCR) and the IDP Working Group (2008). 
Internally Displaced Persons in Iraq. IOM Emergency Needs Assessments - Post-February 2006 Displacement in Iraq: Bi-weekly Report, 15 March - Update 3 February 2008. Retrieved July 10th 2018 from https://reliefweb.int/sites/reliefweb.int/files/reso urces/4CF0F653E2C02BEDC125740F0046277 1-Full_Report.pdf

- University of Dohuk (UoD), Centre for peace and conflict resolutions studies. (2017). Interfaith community dialogue held in Duhok and Erbil. Duhok: Unpublished.

- Weber, M. (1958). The three types of legitimate rule. Berkeley publication on society and institutions, 4(1), 1-11.

- Van Brabant, Koenraad (2000). Operational Security Management in Violent Environments, Good Practice Review 9. London: HPN.

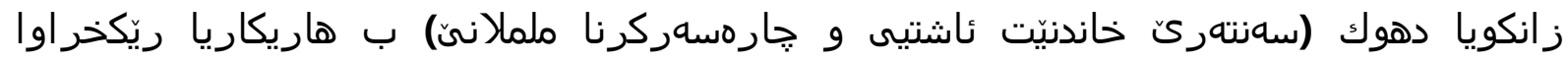

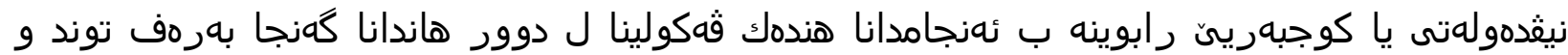

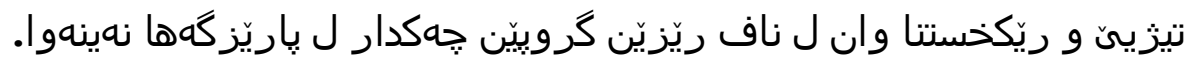

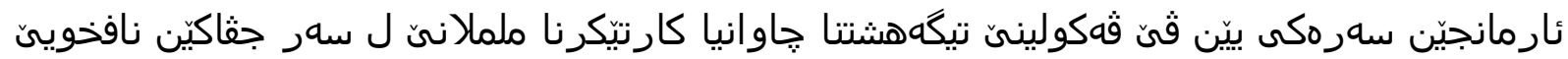

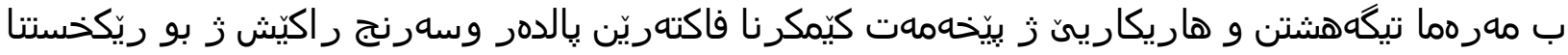

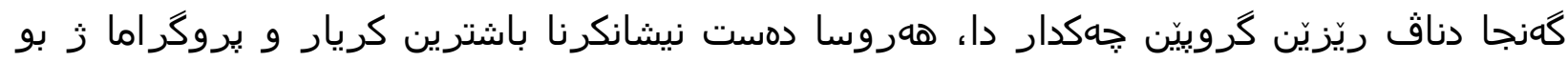

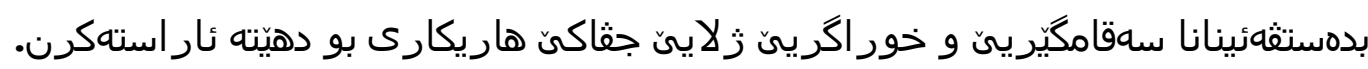

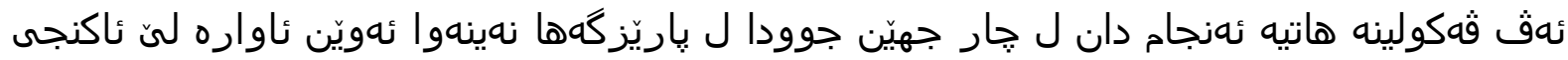

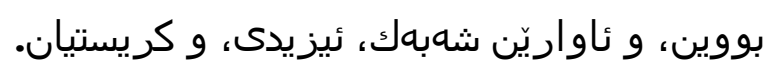

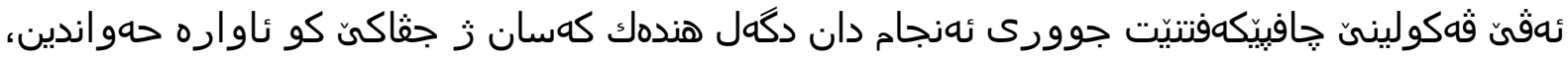

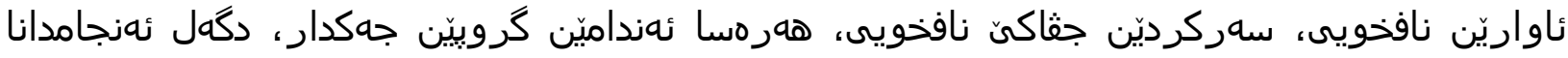

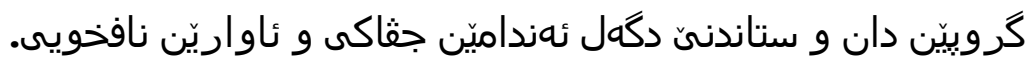

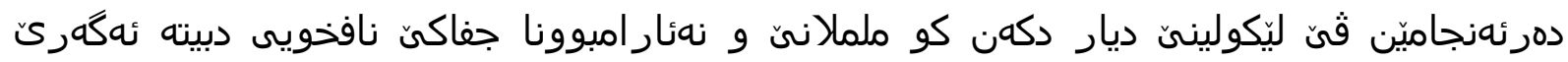

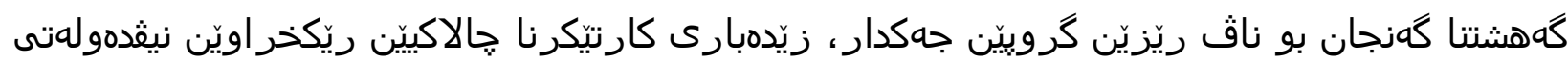

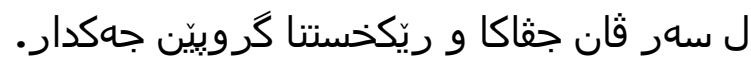

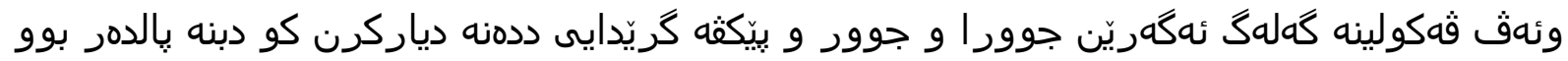

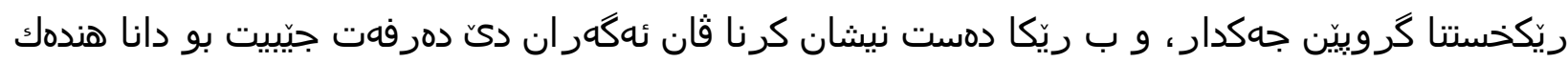

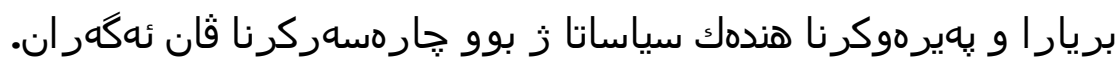

تجنيد النازحين للجماعات المسلحة في محافظة نينوى

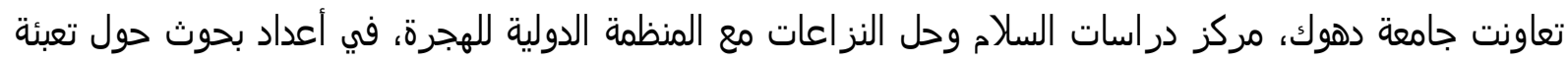

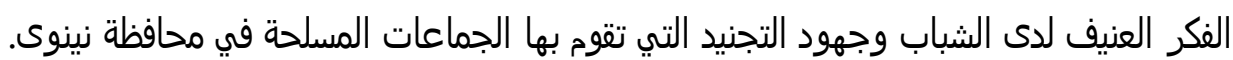

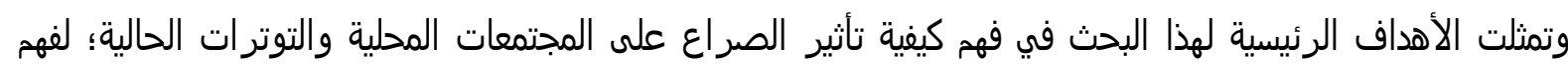

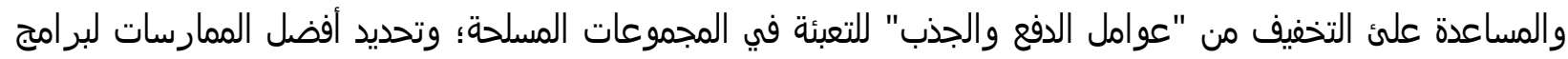
تحقيق الاستقراد والقدرة على الصمود من جانب مجتمع المعان المعونة.

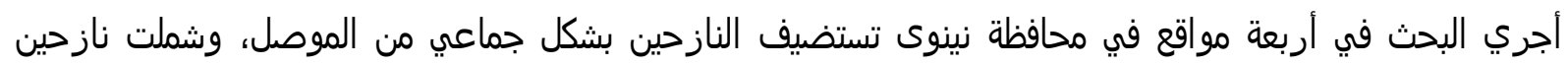

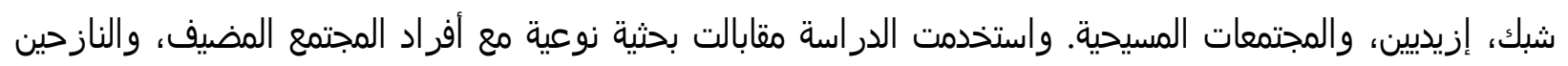


داخليا، وقادة المجتمعات المحلية، وأعضاء الجماعات المسلحة في كل موقع؛ تليها مجموعات التركيز مع أفراد المجتمع والنازحين داخليا.

وتستكشف النتائج الديناميات المحددة للتجنيد، وكيف أن التوتر والصراع داخل المجتمعات المحلية يدفع إلى التجنيد، فضلا عن تأثير أنشطة المنظمات الدولية في نينوى على هذه المجتمعات والتجنيات التنيد.

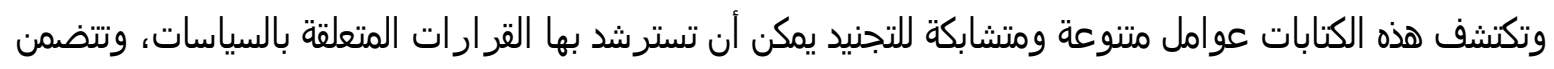
توصيات من المشاركين للمجتمعات المحلية والباحثين والمنظمات الدولية والجهات الفاعلة والحكومات والمجتمع المدني المحلي. 